\title{
Mattia CASULA, Economic Growth and Cohesion Policy Implementation in Italy and Spain: Institutions, Strategic Choices, Administrative Change
}

\section{Spyridon Parthenis}

\section{OpenEdition}

\section{Journals}

Electronic version

URL: https://journals.openedition.org/irpp/2225

DOI: $10.4000 /$ irpp.2225

ISSN: 2706-6274

\section{Publisher}

International Public Policy Association

Printed version

Date of publication: 30 October 2021

Number of pages: 234-237

ISSN: 2679-3873

\section{Electronic reference}

Spyridon Parthenis, "Mattia CASULA, Economic Growth and Cohesion Policy Implementation in Italy and Spain: Institutions, Strategic Choices, Administrative Change", International Review of Public Policy [Online], 3:2 | 2021, Online since 16 December 2021, connection on 16 December 2021. URL: http:// journals.openedition.org/irpp/2225 ; DOI: https://doi.org/10.4000/irpp.2225

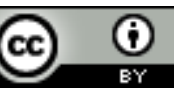

International Review of Public Policy is licensed under a Creative Commons Attribution 4.0 International. 


\section{Book Review}

\section{Mattia CASULA,}

Economic Growth and Cohesion Policy

Implementation in Italy and Spain: Institutions,

Strategic Choices, Administrative Change

\section{Spyridon Parthenis}

PhD student, Department of Tourism Management, University of West Attica, Greece

Economic Growth and Cohesion Policy

Implementation in Italy and Spain: Institutions,

Strategic Choices, Administrative Change

Mattia Casula

Casula, Mattia, London: Palgrave Macmillan (International Series on Public Policy), 2020, 282 p., ISBN 9783030369972. Hardcover: 79.11€, Softcover: 52.74€, eBook: $42.79 €$ 
How can one justify the fact that, 33 years after the pivotal reform of the EU Structural Funds, there are still enduring social, economic, and territorial disparities between the EU's northwestern and its southern and eastern regions? Why are some EU Member States (MSs) doing better than others when it comes to managing and leveraging EU funds? Why is the Brusselsled regional policy, which follows the same implementation mechanisms and rules for all EU MSs, more successful in some regions and less successful in some others, with differing outcomes across different programming periods? Casula's book responds convincingly to the questions above. The author seeks to identify the conditioning political and institutional factors required for the effective implementation of the cohesion policy (independent variable) and explain the resulting contrasting rates of economic growth and convergence (dependent variable) of the less developed EU regions. This book shows that EU Cohesion Policy is difficult to implement evenly across EU countries and regions because of the differences in the capacity of the domestic national and sub-national actors and institutions to manage funds efficiently. The persistent disparate policy outcomes, not only in economic terms but also in social terms, could potentially enhance or undermine the trust of Europeans and the future of the European Union, as well as erode EU values.

EU regional policy remains highly controversial, with inconclusive and ambiguous impacts which do not always persuade European citizens of its effectiveness. This informative and welldocumented book provides an invaluable insight into the workings of the management of EU funds by domestic institutions and actors who have been manoeuvring the cohesion-policy implementation process in Italy and Spain. This astute and perspicacious evaluation study is timely and highly relevant in light of the launch of the new programming period of the EU Cohesion Policy legislative package for 2021-2027. In a post-Brexit era, amid a growing number of Eurosceptic parties and Europeans who seem to be losing faith in the European project - and calling for greater accountability of the EU and of national institutions - this meticulous monograph is a welcome contribution to the literature on Europeanization, historical institutionalism, implementation of public policy, cohesion policy evaluation, endogenous growth theories, and comparative politics.

This book is a comparative qualitative research project, which examines empirically and from the angle of political science the evolution and impacts of the EU Cohesion policy as a case of development policy in Italy and Spain over four programming periods, from 1989 to 2017. To this end, the author develops a conceptual framework, inspired by the work and ideas of the influential German political theorist and economic development expert, Albert Hirschman, who studied various development projects funded by the World Bank around the world in the 1960s. In his books Hirschman stressed that underdeveloped countries typically have surplus productive capacity, so development depends on calling forth and engaging, for development purposes, latent, dispersed and not sufficiently used resources and abilities. He also showed that the objectives of a development project can only be met if the designers sincerely intend to modify the institutional, strategic and administrative environment and that to hasten the pace of economic development in the underdeveloped countries (in this case regions), it is recommendable to beget imbalances purposively. Casula picks up all the above ideas and transforms them creatively into a comprehensive comparative evaluation grid, which prescribes three principles that should be concomitantly present so that a development policy becomes effective in terms of goals pursued: a) promotion of institutional solutions, provided by a central autonomous, politically independent "decision maker responsible for development"; b) promotion of strategic economic choices which improve growth in terms of investment prioritization, in particular territorial and sectoral areas of intervention, coupled with unbalanced 
growth principles; and c) promotion of administrative changes and inducement of feedback effects. The author then uses this framework to conduct an ex-post evaluation of the EU Cohesion Policy to assess its success or failure in terms of economic growth in two Italian and two Spanish less developed regions.

Casula applies deductive reasoning through a pragmatist perspective. Based on the American tradition of development studies, he masterfully constructs a working hypothesis, proposing a Hirshmanian approach to the study of the redistributive financial mechanism of European Structural and Investment Funds. He thus seeks to discover an order which fits the empirical puzzle of the domestic changes that occurred in Italy and Spain after the triple challenge introduced by EU regulations in 1988 and the different ways used by national and sub-national actors to face this challenge. The main strength of the book is the original analytical framework which allows the author to test his provisional theory using evidence. Casula uses a cross-case and within-case comparative-historical or "most similar" case-study research design. To this end, he selects the regions of Calabria and Campania (Italy) and the Galicia and Andalusia regions (Spain) because of their similar contextual traits. Italy and Spain are both regionalized countries of the south, with analogous territorial extension and administrative culture, but with different cohesion policy outcomes reflected in economic growth rates. The author is applying the process tracing method, effectively describing and analyzing trajectories of change during four programming periods in these four regions. He then draws causal inferences from diagnostic pieces of evidence, ranging from analysis of documents produced by EU and national institutions to secondary literature and interviews with EU and national policy elites.

This study confirms that the policy implementation process is a difficult task, as it depends on historical legacies and a complicated series of reciprocal interactions. On the one hand, Casula ascertains that the failure of the Italian regions to manage EU funding efficiently was primarily because of path-dependency constraints and an absence of Hirschmanian principles, which diminished the chances of economic development. This was due to the long-established regional policy and to deep-rooted clientelistic and informal roles established between center and periphery. In addition, the lack of a European management and monitoring culture, combined with immoderate political control, adverse credos, and dogged cultural beliefs, hindered the cementation of good practices and the emergence of a process-oriented culture. He concludes that the Mezzogiorno regions, long doomed to underdevelopment, were trapped in an image of constant self-victimization, which may be exploited by regional actors to elicit more EU funding. On the other hand, Casula attributes the success of the Spanish regions to a greater closeness to Hirschmanian principles, which increased the chances of economic growth. This was possible because there had been no pre-existing structure for regional policy, which allowed better alignment of the Spanish actors with European regulations. Moreover, there was, all along, a strong national coordination mechanism in Madrid, staffed by qualified technical experts, which permitted the development of a bureaucratic autonomy within regions and the non-consolidation of distorted practices.

The book is best suited for EU bureaucrats, national and regional policymakers, public administrators in national, regional and local authorities, economic development and evaluation experts, political scientists, economic geographers, and regional economists. It could be adopted as part of the curriculum in graduate courses on regional science, public administration, economic and development geography, public policy, and European Studies.

The book would be easier to read if it included summary tables with the evolution of regional GDP from 1988 onwards in the regions studied, and the demographic and occupational struc- 
ture of the population, as well as the sectoral composition of each region's economy. Casula could also briefly discuss the critical geography concept of spatial justice, linked to territorial cohesion, and highlight the stance of the EU, which is occasionally contradictory and disorienting, seeking to reconcile neoliberal macro-economic priorities and instill solidarity and social inclusion. Overall, this is a robust evaluation study which could serve as a springboard for further qualitative and quantitative research projects, comparing EU MSs and regions with similar characteristics. 